\title{
Kinerja Sumber Daya Manusia di Rumah Potong Hewan (Studi Kasus RPH Kategori I dan Kategori II)
}

\author{
Performance of Human Resources in Slaughtering House (Study Case Abattoir Category I and Abattoir \\ Category II) \\ N. A. D. Tiya ${ }^{1 *}$, H. Nuraini ${ }^{2,3}$, \& L. Cyrilla E. N. S. D ${ }^{2}$ \\ ${ }^{1}$ Program Studi Ilmu Produksi dan Teknologi Peternakan, Sekolah Pascasarjana, IPB University, Bogor, \\ 16680, Indonesia. \\ ${ }^{2}$ Departemen Ilmu Produksi dan Teknologi Peternakan, IPB University, Bogor, 16680, Indonesia. \\ ${ }^{3}$ Pusat Kajian Sains Halal IPB University, Bogor, 16680, Indonesia. \\ *Corresponding author: ningayu060794@gmail.com \\ (Received 11-02-2021; Revised 24-03-2021; Accepted 26-04-2021)
}

\begin{abstract}
This study aims to identify the characteristics of human resources in slaughterhouses category I and category II, as well as to analyze the performance and efficiency of human resources in slaughterhouses category I and category II. Location samples and respondents were determined purposively. The variables observed were the characteristics of my human source, my human source performance, and the efficiency of my human source performance in category I and category II slaughterhouses. The results showed that the characteristics of category I and category II employees had an average high school education, 30-40 years of age and 10-20 years of work. The performance of my human resources (work results, skills, discipline and responsibility) of each slaughterhouse has a fairly good percentage, slaughterhouse for category I (77.66-80.95\%) and slaughterhouse for category II (81.68-83.59\%) . The performance efficiency figures for the employees of the slaughterhouse category I and category II are similarly close to number 1 indicating that the employees' working time is used efficiently.
\end{abstract}

Keyword: Performance, Human resources, Slaughterhouses, Category I, Category II

\begin{abstract}
ABSTRAK
Penelitian ini bertujuan untuk mengidentifikasi karakteristik Sumber Daya Manusia (SDM) di Rumah Potong Hewan (RPH) kategori I dan kategori II, serta menganalisis kinerja dan efisiensi kinerja SDM di RPH kategori I dan kategori II. Sampel lokasi dan responden ditentukan secara purposive. Peubah yang diamati yaitu karakteristik SDM, kinerja SDM, dan efisiensi kinerja SDM di RPH kategori I dan kategori II. Hasil penelitian memperlihatkan bahwa karakteristik karyawan kategori I dan kategori II rata-rata memiliki pendidikan SMA, umur 30-40 tahun dan lama bekerja 10-20 tahun. Kinerja SDM (hasil kerja, keterampilan, disiplin dan tanggung jawab) masing-masing RPH memiliki persentase yang cukup baik, RPH Kategori I (77.66-80.95\%) dan RPH Kategori II (81.68-83.59\%). Angka efisiensi kinerja karyawan RPH kategori I dan RPH kategori II sama-sama mendekati angka 1 menunjukkan bahwa waktu kerja karyawan yang digunakan efisien.
\end{abstract}

Kata kunci: Kinerja, Sumber daya manusia, Rumah potong hewan, Kategori I, Kategori II

\section{PENDAHULUAN}

Seiring bertambahnya jumlah penduduk setiap tahunnya memengaruhi jumlah konsumsi protein hewani. Adanya peningkatan volume permintaan daging harus diimbangi dengan peningkatan volume penyediaan daging di masyarakat. Daging harus higienis, sehat, dan halal agar masyarakat mengkonsumsi secara aman.
Salah satu lembaga yang menyediakan proses pemotongan secara higienis adalah Rumah Potong Hewan (RPH). Lembaga yang menyediakan fasilitas pemotongan ternak atau RPH sebagai unit sarana pelayanan kepada masyarakat dalam penyediaan daging Aman Sehat Utuh Halal (ASUH) (Soeparno et al. 2007).

RPH terbagi atas 2 (dua) kategori yaitu RPH kategori I dan kategori II. Kategori I adalah RPH yang tidak 
memiliki fasilitas pelayuan (aging) karkas, dan biasanya hanya menghasilkan karkas hangat. Kategori II adalah RPH yang memiliki fasilitas pelayuan karkas, yang bertujuan menghasilkan karkas dingin (chilled) atau beku (frozen). RPH kategori I biasanya dalam proses pasca pemotongan daging atau karkas langsung dibawa oleh pedagang dan dijual dalam keadaan panas (Hot meat). RPH kategori II atau bisa disebut RPH modern dalam proses pasca pemotongan daging atau karkas melalui proses pelayuan, setelah proses pelayuan dilakukan deboning untuk membentuk potongan komersial karkas (No 13/Permentan/OT.140/1/2010).

Rumah potong hewan merupakan lembaga atau organisasi yang manajamennya salah satunya dipengaruhi oleh kualitas Sumber Daya Manusia (SDM). Syarat SDM RPH menurut Permentan No 13 Tahun 2010 minimal memiliki karyawan masing-masing satu dokter hewan, keurmaster, butcher dan juru sembelih halal. SDM berkaitan dengan perencanaan yang digunakan semaksimal mungkin. SDM memberikan sumbangan kepada tempat kerja dan kesejahteraan individu. Hal ini disebabkan oleh faktor fisik, Effendy (1991) menyatakan bahwa faktor fisik SDM adalah modal dan tenaga kerja.

Kinerja merupakan prestasi kerja atau hasil kerja yang dicapai oleh SDM (Putri dan Ratnasari 2019). Kinerja SDM RPH sangat menentukan keberhasilan pengelolaan RPH agar mampu menghasilkan produk daging yang berkualitas untuk masyarakat. Kinerja SDM merupakan suatu investasi bagi RPH dan mendukung proses pengelolaan RPH yang optimal. Kinerja SDM yang berkualitas akan mampu mewujudkan tujuan RPH. Kinerja SDM sangat penting bagi RPH serta menjadi sumber keunggulan karena dengan adanya SDM yang berkualitas berperan penting dalam mejalankan perusahaan.

Tujuan dari penilitian ini adalah mengidentifikasi uraian pekerjaan SDM di RPH kategori I dan kategori II, serta menganalisis kinerja dan efisiensi kinerja SDM di RPH kategori I dan kategori II.

\section{METODE PENELITIAN}

\section{Waktu dan Lokasi Penelitian}

Penelitian telah dilaksanakan pada bulan Desember 2018 sampai Mei 2019 bertempat di 2 RPH yaitu RPH kategori I di Bogor dan RPH kategori II di Bogor. Pemilihan RPH yang dijadikan lokasi penelitian dilakukan secara purposive. Dasar yang digunakan adalah ada tidaknya fasilitas pelayuan di RPH tesebut.

\section{Responden dan Data}

Jenis data yang diambil adalah data sekunder dan data primer. Data sekunder diperoleh melalui literatur, laporan perusahaan atau instansi, dan pustaka lainnya. Data sekunder yang diamati pada penelitian ini yaitu kondisi umum tempat penelitian, definisi dan struktur organisasi perusahaan, bagan kegiatan di RPH tersebut, serta data kepegawaian perusahaan yang bersangkutan. Sedangkan data primer diperoleh melalui pengamatan langsung dengan melakukan wawancara dan pengisian kuesioner oleh responden. Samling purposive merupakan metode yang dugunakan dalam menentukan sampel responden/karyawan. Metode ini digunakan untuk menentukan sampel penelitian dengan pertimbangan tertentu (Sugiyono 2004). Pertimbangan tersebut, berdasarkan jabatan atau posisi jabatan karyawan dan kesediaan karyawan untuk diwawancara.

Pengumpulan data pada penelitian ini menggunakan beberapa metode yaitu sebagai berikut: 1). Observasi, pengamatan secara langsung di lokasi penelitian; 2). Wawancara, melakukan wawancara secara langsung atau mengisi kuesioner yang diberikan kepada responden/ karyawan; 3). Studi pustaka, mengumpulkan data melalui literatur dan bahan rujukan lain yang berhubungan dengan penelitian yang dilakukan.

\section{Peubah yang Diamati}

\section{a. Karakteristik SDM RPH}

Karakteristik SDM yang diamati pada RPH kategori I dan kategori II terdiri dari: Profil RPH, pendidikan, umur, pengalaman kerja, karyawan RPH yang disesuaikan berdasarkan Peraturan Permentan No 13 Tahun 2010, serta pengetahuan tentang kesejahteraan hewan (KESRAWAN). Data yang diperoleh di lapangan kemudian dianalisis secara deskriptif, data ditabulasikan, dan dirata-ratakan.

\section{b. Kinerja SDM RPH}

Kinerja SDM adalah istilah yang muncul berdasarkan kata actual performance (prestasi sesungguhnya yang dicapai seseorang) atau job performance (prestasi kerja) (Abdurrahman, 2017). Prestasi kerja atau kinerja karyawan merupakan hasil pekerjaan yang secara kuantitas dan kualitas diperoleh oleh karyawan berdasarkan tugas yang diberikan kepadanya, dan dikerjakan sesuai dengan tanggung jawab pekerjaannya. Menurut Abdurrahman (2017), kinerja merupakan gambaran pencapaian tugas oleh karyawan yang diberikan oleh perusahaan atau organisasi tempat karyawan bekerja, untuk mewujudkan sasaran, tujuan, misi, dan visi perusahaan atau organisasi bersangkutan.

Tolak ukur kinerja karyawan menurut Wungu dan Brotoharsojo (2003), dapat diukur berdasarkan :

1. Hasil kerja, adalah kualitas dan kuantitas hasil kerja yang akan dicapai oleh karyawan dibandingkan dengan sasaran kerja individu pada jabatannya.

2. Keterampilan kerja, adalah keahlian karyawan dalam melaksanakan tugas-tugasnya menggunakan peralatan, manual baku atau teknis administratif tertentu.

3. Disiplin, adalah pelaksanaan karyawan dalam bekerja yang tetap menataati prosedur dan peraturan yang ada dalam perusahaan agar pekerjaan tetap berjalan dengan tertib dan lancar.

4. Tanggung jawab, adalah kesediaan karyawan untuk menyelesaikan tugas jabatan yang lebih berat dari pada yang telah dilaksanakannya sehari-hari.

Penilaian kinerja karyawan (hasil kerja, keterampilan, disiplin, dan tanggung jawab) RPH kategori I dan kategori II dihitung memakai skala likert 5 (lima) point \{1 (sangat tidak setuju), 2 (tidak setuju), 3 (kurang setuju), 4 (setuju), 5 (sangat setuju)\}. Skala likert adalah skala yang dipakai untuk menentukan sikap atau pendapat serta presepsi individu atau kelompok mengenai fenomena sosial atau peristiwa 
berdasarkan definisi operasional yang telah ditetapkan oleh peneliti (Mawardi 2019).

\section{c. Efisiensi kinerja karyawan}

Menurut Render dan Heizer (2007), efisiensi adalah ukuran output aktual (yang sebenarnya dihasilkan) dengan kapasitas efektif. Efisiensi memiliki kaitan dengan pengeluaran yang dilakukan dalam rangka pencapaian tujuan, dalam penelitian ini efisiensi diukur berdasarkan waktu (jam) yang dikeluarkan oleh karyawan selama bekerja di RPH.

\section{d. Analisis Data}

Data yang analisis pada penelitian ini adalah adalah:

1. Profil SDM RPH, pendidikan, umur, dan pengalaman kerja, dianalisis secara kualitatif deskriptif.

2. Kinerja SDM di RPH kategori I dan kategori II diukur berdasarkan hasil kerja, kemahiran, disiplin dan tanggung jawab. Penilaian SDM RPH tersebut, dihitung memakai skala likert 5 (lima) point yaitu $\{1$ (sangat tidak setuju), 2 (tidak setuju), 3 (kurang setuju), 4 (setuju), 5 (sangat setuju)\}.

3. Efisiensi kinerja karyawan diukur berdasarkan waktu (jam) kerja, dihitung sesuai dengan rumus dari Render dan Heizer (2007):

$$
\text { Efisiensi }=\frac{\text { Output aktual }(\mathrm{jam})}{\text { Kapasitas ef ektif }(\mathrm{jam})}
$$

\section{HASIL DAN PEMBAHASAN}

\section{Karyawan RPH sesuai dengan Peraturan Permentan No 13 Tahun 2010}

Berdasarkan UU No.18 tahun 2009 tentang peternakan dan kesehatan hewan menyatakan bahwa setiap kabupaten atau kota harus memiliki RPH (Rumah Potong Hewan) yang sesuai prosedur. Pelaksanaan dari UU tersebut adalah keluarnya keputusan Kementerian Pertanian No. 13 tahun 2010, bahwa syarat untuk mendirikan RPH salah satunya adalah memiliki minimal 1 dokter hewan sebagai unit pelaksana teknis, 1 keurmaster yang dibawahi langsung dokter hewan sebagai unit pemeriksa daging, 1 juru sembelih halal dan 1 butcher sebagai ahli pemotong karkas dan bagian-bagiannya. Hasil penelitian menunjukkan RPH kategori I dan II telah memenuhi syarat yaitu memiliki karyawan dengan posisi dokter hewan, keurmaster, juru sembelih halal dan butcher (Tabel 1).

\section{Profil SDM RPH}

\section{a. RPH Kategori I}

Pegawai negeri sipil (PNS) di RPH kategori I terdiri atas Kepala UPTD, administrasi keuangan, kasubak tata usaha, administrasi karcis, pengelola rumah potong hewan, pramu kebersihan, pengawas lalulintas hewan dan wilayah, dokter hewan, juleha dan kuermaster. Jumlah total pegawai keseluruhan adalah 15 orang. Jumlah jam kerja masingmasing karyawan yaitu 8 jam perhari dari hari Senin sampai hari Jumat pukul 07.30-16.00 WIB. Hal ini sesuai dengan peraturan kementerian Pendayagunaan Aparatur Negara dan Reformasi Birokrasi (PANRB) bahwa jam kerja diatur dalam pasal 3 ayat 1, mulai dari senin hingga kamis pukul 07.30-16.00 WIB, dan jam istirahat pukul 12.00-13.00 WIB. Sedangkan jam kerja hari Jumat mulai dari pukul 07.30-16.30 WIB dan jam istrahat pukul 11.30-13.00 WIB.

Proses pemotongan ternak dilakukan pada saat malam hari yaitu mulai dari jam 21.00-05.00 WIB. Khusus untuk juleha jam masuk kerja malam hari yaitu pada saat pemotongan ternak. Dokter hewan dan kuermaster secara bergantian memiliki sistem piket malam untuk mengawasi proses pemotongan di RPH dan ketika jadwal piket maka diizinkan untuk tidak masuk kantor di pagi hari.

RPH kategori I memiliki satu dokter hewan yang statusnya sebagai Tenaga Kerja Harian Lepas THL, lama masa kerja di RPH sesuai dengan kontrak yang disepakati dengan pemerintah. Tenaga Kerja Harian Lepas (THL) adalah pekerjaan yang gajinya dihitung berdasarkan jumlah volume, waktu dan kehadiran. Hal ini sesuai dengan bunyi pasal 10 ayat 1 Kepmen Nomor 100 tahun 2004, bahwa upah/gaji untuk tenaga kerja harian lepas didasarkan dari kehadiran, besarnya jumlah upah/gaji pekerja biasanya tergantung dari jumlah volume pekerjaan yang diselesaikan dalam satu hari.

Pekerja harian merupakan tenaga kerja yang bekerja pada saat proses pemotongan yang tugasnya adalah menangani ternak setelah proses pemotongan hingga pembelahan karkas. Jumlah tenaga kerja dan upah pekerja harian ditentukan oleh pemilik sapi. Rata-rata pemilik sapi yang melakukan proses pemotongan di RPH kategori I memiliki pekerja harian 3-5 orang. Status karyawan di RPH kategori I dan kategori II, secara rinci disajikan pada Tabel 2 .

\section{b. RPH Kategori II}

Karyawan di RPH kategori II terbagi atas 3 status yaitu pegawai tetap, pegawai kontrak dan casual. Pegawai tetap merupakan karyawan yang yang gajinya sudah pasti

Tabel 1. Posisi dan sertifikat karyawan RPH sesuai dengan Permentan No 13 Tahun 2010

\begin{tabular}{lccccc}
\hline \multirow{2}{*}{ Posisi } & Syarat Jumlah & \multicolumn{2}{c}{ Katagori I } & \multicolumn{2}{c}{ Katagori II } \\
\cline { 3 - 6 } & & Karyawan & Sertifikat & Karyawan & Sertifikat \\
\hline Dokter hewan & 1 & 2 & 2 & 1 & 1 \\
Kuermaster & 1 & 2 & 2 & 2 & 2 \\
Juru sembelih halal & 1 & 2 & 2 & 3 & 3 \\
Butcher & 1 & 1 & 1 & 21 & 21 \\
\hline
\end{tabular}


Tabel 2. Status karyawan RPH kategori I dan kategori II

\begin{tabular}{lc}
\hline \multicolumn{1}{c}{ Status Karyawan } & Jumlah \\
\hline Pegawai Negeri Sipil (PNS) & 1 \\
Kepala UPTD RPH Terpadu & 1 \\
Administrasi keuangan & 1 \\
Kasubak tata usaha & 2 \\
Administrasi karcis & 1 \\
Bagian produksi & 5 \\
Pramu Kebersihan & 2 \\
Pengawas lalulintas hewan dan wilayah /kuermaster & 1 \\
Dokter Hewan & 1 \\
Juru sembelih halal & \\
Tenaga Harian Lepas (THL) & 1 \\
Dokter Hewan & \\
Sukarelawan (SUKWAN) & \\
Security & 5 \\
Butcher & 1 \\
Kebersihan & 47 \\
Loket/penimbangan & 4 \\
Juru sembelih halal & 3 \\
Pekerja Harian & 1 \\
\hline Jumlah & 48 \\
\hline
\end{tabular}

didapatkan setiap bulan dan memiliki keterampilan yang khusus. Adapun yang termasuk pegawai tetap di RPH Kategori II yaitu manajer, HRD, supervisior, dokter hewan, QA, QC dan operator gudang. Pegawai kontrak merupakan karyawan yang telah memiliki pengalaman yang cukup lama dalam menangani proses pemotongan ternak, sistem upah juga diberikan perbulan. Pekerjanya terdiri atas slicer, boner, maintance, juleha, stunning, clining dan security. Karyawan pegawai kontrak setiap tahun menandatangani kontrak jika tetap lanjut bekerja di RPH. Casual adalah tenaga kerja tambahan yang ditugaskan jika RPH kekurangan tenaga kerja atau pemotongan sapi yang cukup banyak.

Jadwal karyawan RPH kategori II yaitu 6 kali dalam seminggu, 3 hari melakukan proses pemotongan dan 3 hari deboning. Jam kerja mulai pada pukul 07.30 WIB dan selesai kurang lebih pukul 16.00 WIB. Jam Istirahat dua kali yaitu pukul 9.30-10.00 WIB dan pukul 12.00-13.00 WIB. Rata-rata jumlah ternak sapi yang dipotong berjumlah 50-60 ekor hari-1. Status karyawan di RPH kategori II, secara rinci disajikan pada Tabel 3.

\section{Karakteristik Pendidikan, Umur, dan Pengalaman Karyawan RPH}

Syarat pendidikan lebih diutamakan untuk dokter hewan dan keurmaster, sedangkan untuk posisi butcher dan juleha pendidikan bukan menjadi syarat utama untuk bekerja di RPH. Umumnya karyawan diterima karena telah memiliki keahlian atau pengalaman dalam menangani proses pemotongan ternak. Karyawan yang telah terpilih akan dibekali tentang tata cara pemotongan ternak dan pengetahuan tentang kesejahteraan hewan. Menurut Xeviria et al. (2016) pelatihan yang diberikan pada karyawan merupakan kegiatan untuk menyelesaikan persoalan yang akan dihadapi secara tepat dan cepat, yang nantinya dapat meningkatkan kinerja karyawan sesuai dengan keinginan perusahaan atau organisasi.

Berdasarkan data pada Tabel 4, terlihat bahwa ratarata usia karyawan RPH kategori I dan kategori II dalam usia produktif (30-40 tahun). Menurut Badan Pusat Statistik bahwa penduduk usia produktif adalah usia 15 tahun sampai 64 tahun. Berdasarkan hasil tersebut dapat dilihat bahwa tingkat produktivitas justru semakin bertambah seiring dengan bertambahnya usia. Pendapat ini sejalan dengan Sudijanto (1999) yang menyatakan bahwa tenaga kerja atau kayawan yang semakin dewasa memiliki daya serap pemahaman akan inovasi baru dengan penerapan yang baru dapat dengan mudah diterima, serta pengalaman yang lebih mumpuni.

Hasil wawancara pada karyawan RPH kategori I dan II memiliki pengamalan bekerja yang bervariasi (Tabel 4). RPH Kategori I memiliki pengalaman karyawan tertinggi di $<10$ tahun (57.14\%) dan Kategori II di 10-20 tahun $(66.67 \%)$. Pengalaman kerja tersebut berpengaruh terhadap keterampilan kerja. Selain itu, masa kerja

Tabel 3. Status karyawan RPH kategori I dan kategori II

\begin{tabular}{|c|c|}
\hline Status Karyawan & Jumlah \\
\hline \multicolumn{2}{|l|}{ Pegawai Tetap } \\
\hline Manajer & 1 \\
\hline HRD & 1 \\
\hline Supervisior & 2 \\
\hline Dokter Hewan & 1 \\
\hline QA & 1 \\
\hline QC & 1 \\
\hline Operator Gudang & 1 \\
\hline \multicolumn{2}{|l|}{ Pegawai Kontrak } \\
\hline Slicer & 10 \\
\hline Boner & 7 \\
\hline Maintance & 1 \\
\hline Juleha & 2 \\
\hline Stuning & 2 \\
\hline Clining & 3 \\
\hline Security & 6 \\
\hline \multicolumn{2}{|l|}{ Casual } \\
\hline Stuning & 1 \\
\hline Slicer & 4 \\
\hline Beging & 2 \\
\hline Vakum & 4 \\
\hline Packing & 3 \\
\hline Portioning & 4 \\
\hline Juleha & 1 \\
\hline Clining & 4 \\
\hline Gudang & 4 \\
\hline Jumlah & 66 \\
\hline
\end{tabular}


Tabel 4. Karakteristik pendidikan, umur, pengalaman SDM di RPH kategori I dan kategori II

\begin{tabular}{lcccc}
\hline \multirow{2}{*}{ Karakteristik } & \multicolumn{2}{c}{ RPH kategori I } & \multicolumn{2}{c}{ RPH kategori II } \\
\cline { 2 - 5 } & $\mathrm{N}$ & $\%$ & $\mathrm{~N}$ & $\%$ \\
\hline Pendidikan & & & & \\
SD & 0 & 0.00 & 2 & 7.41 \\
SMP & 0 & 0.00 & 4 & 14.81 \\
SMA & 3 & 42.86 & 18 & 66.67 \\
Diploma & 2 & 28.57 & 2 & 7.41 \\
S1 & 2 & 28.57 & 1 & 3.70 \\
Umur & & & & \\
$<30$ & 1 & 14.29 & 5 & 18.52 \\
$30-40$ & 5 & 71.43 & 15 & 55.56 \\
$>40$ & 1 & 14.29 & 7 & 25.93 \\
Pengalaman & & & & \\
$<10$ & 4 & 57.14 & 9 & 33.33 \\
$10-20$ & 2 & 28.57 & 18 & 66.67 \\
$>20$ & 1 & 14.29 & 0 & 0.00 \\
\hline $\mathrm{n}=$ jumlah individu & & & &
\end{tabular}

menentukan kondisi pengalaman seorang pekerja dalam bekerja di rumah potong hewan. Pengalaman ini yang nantinya membantu pekerja dalam mengambil keputusan yang cepat saat bekerja. Hal ini sesuai dengan Sudaryat (2007) yang menjelaskan bahwa pengalaman merupakan akumulasi proses belajar yang dialami oleh seseorang, yang menjadi satu dasar pertimbangan dalam menerima ide baru. Karakteristik pendidikan, umur, pengalaman karyawan RPH kategori I dan kategori II, secara rinci disajikan pada Tabel 4.

\section{Kinerja SDM RPH}

Hasil penelitian memperlihatkan bahwa pengukuran kinerja karyawan (hasil kerja, keterampilan kerja, disiplin, ketepatan waktu, dan tanggung jawab) memiliki persentase yang baik sebesar RPH kategori I (77.66-80.95\%) dan RPH kategori II (81.68-83.59\%). RPH Kategori II memiliki rataan pengukuran kinerja dan penilaian kinerja karyawan diatas $80 \%$. Hal ini dikarenakan karyawan RPH Kategori II lebih ditekankan untuk tepat waktu masuk kantor dan sebelum masuk kantor diadakan briefing untuk membahas kekurangan atau keselahan karyawan ketika sedang bekerja. Kinerja SDM RPH, secara rinci dapat dilihat pada Tabel 5.

Tabel 5. Kinerja Karyawan RPH Kategori I dan Kategori II

\begin{tabular}{lcccc}
\hline \multirow{2}{*}{ Variabel } & \multicolumn{2}{c}{ RPH Kategori I } & \multicolumn{2}{c}{ RPH Kategori II } \\
\cline { 2 - 5 } & Nilai & $\%$ & Nilai & $\%$ \\
\hline Hasil Kerja & 3.95 & 78.90 & 4.11 & 82.20 \\
Keterampilan Kerja & 3.88 & 77.66 & 4.08 & 81.68 \\
Disiplin & 4.02 & 80.41 & 4.17 & 83.41 \\
Tanggung Jawab & 4.05 & 80.95 & 4.18 & 83.59 \\
\hline
\end{tabular}

\section{Efisiensi Kinerja SDM}

Angka efisiensi yang mendekati angka 1 menunjukkan bahwa waktu kerja karyawan yang digunakan semakin efisien, begitu juga sebaliknya. Baik RPH kategori I dan II memiliki waktu kerja selama 8 jam per hari, dan berdasarkan hasil yang diperoleh rata-rata karyawan bekerja sesuai dengan waktu yang ditentukan oleh RPH (kantor). Hal ini sesuai dengan pendapat Coelli (1996) bahwa nilai efisiensi yang diperoleh merupakan hasil rasio input terhadap output. Kinerja kayawan dikatakan semakin efisien secara teknis ketika nilai efisiensinya mendekati angka 1 (satu), sedangkan tidak efisien ketika mendekati angka 0 (nol). Efisiensi kinerja karyawan di RPH kategori I dan kategori II, secara rinci dapat dilihat pada Tabel 6.

Tabel 6. Efisiensi kinerja karyawan

\begin{tabular}{lcc}
\hline \multicolumn{1}{c}{ Efesiensi } & ${ }^{\mathrm{a}}$ Kategori I & ${ }^{\mathrm{b}}$ Kategori II \\
\hline Output aktual & 217 & 192 \\
Kapasitas efektif & 240 & 208 \\
\hline Nilai efesiensi & 0.90 & 0.93 \\
\hline * a : hari kerja selama 1 bulan (30 hari); b : hari kerja selama 1 \\
bulan (25 hari)
\end{tabular}

\section{KESIMPULAN}

Karakteristik karyawan RPH kategori I dan kategori II rata-rata memiliki pendidikan SMA, umur 30-40 tahun dan lama bekerja 10-20 tahun. Kinerja karyawan RPH kategori I dan kategori II memiliki nilai persentase hasil kerja, keterampilan, disiplin, dan tanggung jawab yang cukup baik. Efesiensi kinerja karyawan RPH kategori I dan kategori II memiliki nilai masing-masing 0.90 dan 0.93 yang berarti mendekati angka 1 menunjukkan waktu kerja karyawan sudah efisien.

\section{DAFTAR PUSTAKA}

Abdurrahman,J.2017. Faktoryangmempengaruhi evaluasi kinerja para pegawai di kantor pemerintahan. PIONIR: Jurnal Pendidikan. Vol. 6(1): 151-165.

Dharma, A. 2003. Manajemen Supervisi : Petunjuk Praktis bagi para Supervisor. Jakarta (ID): Raja Grafindo Persada.

Effendi, S. 1991. Kebijaksanaan Pengembangan Sumber Daya Manusia Menghadapi Era Tinggal Landas. Jurnal Populasi. Vol. 1(2): 1-10.

Mathis, R. L. \& J. H. Jackson. 2002. Manajemen Sumber Daya Manusia. Salemba Empat : Jakarta.

Mawardi, M. 2019. Rambu-rambu Penyusunan Skala Model Likert untuk Mengukur Sikap Siswa. Jurnal Pendidikan Dan Kebudayaan. Vol. 9(3): 292-304.

Prawirosentono, S. 2008. Manajemen Sumberdaya Manusia Kebijakan Kinerja Karyawan. Yogyakarta (ID): UGM Press.

Putri, N. R. \& S. L. Ratnasari. 2019. Pengaruh Tingkat Pendidikan, Pelatihan, dan Pengembangan Karir terhadap Kinerja Karyawan PT. Asuransi Takaful Batam. Jurnal Akuntansi, Ekonomi dan Manajemen Bisnis. Vol. 7(1): 48-55. 
Render, B. \& J. Haizer. 2007. Principles of Operations Management: Alih bahasa oleh Kresnohadi. Bandung (ID): Edisi ketujuh, Salemba Empat.

Rosyidi, J. 2017. Rumah Potong Hewan dan Teknik Pemotongan Ternak Secara Islami. Malang (ID): Universitas Brawijaya Press.

Sedarmayanti. 2009. Sumber Daya Manusia dan Produktivitas Kerja. Bandung (ID): CV. Mandar Maju.

Soedijanto, P. 1999. Media Penyuluhan Pertanian. Jakarta (ID): Universitas Terbuka.

Soeparno, T. Prasetyo, Rusman, \& A. Prasetyo. 2007. Studi Pemotongan Sapi dan Kualitas Fisikokimia Daging Sapi Glonggongan. Jurnal KKP3T. Vol. 2(7): 124-126.
Sudaryat, S. 2007. Kapita Selekta Gastroenterologi Anak. Jakarta (ID): Sagung Seto.

Sugiyono. 2004. Metode Penelitian Bisnis. Bandung (ID): CV. Alfabeta.

Sumanth, D. J. 1985. Productivity Engineering and Management. New York (USA): Mc Graw Hill Book Company.

Wungu, J. \& H. Brotoharsojo. 2003. Tingkatkan Kinerja Perusahaan Anda Dengan Merit Sistem. Jakarta (ID): PT. Raja Grafindo Persada.

Xeviria, F., A. Djumlani, \& B. Irawan. 2016. Pelaksanaan Pendidikan dan Pelatihan Aparatur dalam Meningkatkan Kinerja Pegawai di Kantor Dinas Pertambangan dan Energi Kabupaten Kutai Barat Tahun 2015. Jurnal Administrative Reform (JAR). Vol 4(3): 182-193. 